\title{
An Islamic View of Death and Dying
}

\author{
Wahaj D. Ahmad. MD \\ Chapel Hill, North Carolina
}

\begin{abstract}
The definition of death, its certainty and its significance are given based on Qur'anic verses. Dealing with a dying person and the rituals performed in case of death are discussed based on the Qur'an and Hadith. The concept of resurrection is central to Islamic belief.
\end{abstract}

Key words: đeath, Rüh (Soul), Islamic belief

\begin{abstract}
"Every soul shall caste dealh. . . ." is a wcll-known and well-understood "ayah" of the Qur'ān. Everyday human experience makes it quite evident that death is an inseparable part of life. Everyuling that lives must die.

Elizabelh Kubler-Ross publislied her book On Death and Dying in 1969." She attempted to bring to light the psychological attiludes toward death and described four stages in the acceplance of death by individuals who know they are dying. She failed to incorporate religious views of dying. Yet. every culture, ancient or recent, Eastern or Western, black or whitc, Muslim or non-Muslim, has its own beliês, taboos, and religious dictates regarding dying and the perceptions of death. Take for example the indestructibility or immortality of the soul, a concept that is common to many religions. Hindu teachings ${ }^{3}$ indicate that the soul passes at death to alother body, even if the body is nonhunian

Islamic teachings of cschatology are, however, different. Alläh [SWT] says in the Qur'ān al-Majid:

"O ye who believe lel there be witnesses between you when death drawelh near unio one of you, at the time of bequest ...." Also:
\end{abstract}

"Il is prescribed when deatl approaches any one of you.

From the Department of Neurology

University of North Carolinn

Chapel Hill, Norih Carolinn

Reprint requesis:

Wahaj D. Ahmad, MD

576 Townhouse Lane

Fayelleville, NC 2831I if he leaves wealth, that he make a bequest to parents and next of kin according to reasonable usage ...." These and other "ayat" (verses) give details of how a dying Muslim should divide and distribute his property. Rasìl-Allāh [PBUH] advised Muslims to visit the sick, especially when death is near, and advised them to recite the "Shähädah" (the Islamic article of faith [witness]) or "Surät Yasisn" and that the dying person should recite the Shahadah. 'Abü $S$ aid al-Khudri [RAA] narrated that the prophet [PBUH] said:

"Instruct the dying person to say, 'Là ilăha illāllāh" (There is no god but God [Allah]). ${ }^{6}$

For Muslims, it is clear that Allāh, not man, is in charge of death, as revealed in the following verses:

". . at length when death approaches one of you, our angels take his soul ..." and

"It is He who doth take your souls by night and hath knowledge what ye have done by day. Then He doth raise you up again that a term appointed be fulfilled ... ." Then again,

"It is Allah that taketh the souls (of men) al death and those that die not, He takes during their sleep. Those on whom He has passed the decree of death He kecps back (from returning to life) but the rest He sends (back to their bodies) for a term appointed." These 'ayat tell us that the permanent disconnection of soul from body is death. Much of death remains a mystery to men, as Allāh reminds us that

$" .$. of knowledge it is only a little that is given to you." "11

There are about 165 aya concerning death in the Qur'ăn al-karim, but we need concern ourselves with only a few for the sake of understanding the concept of dealh as 
Muslims.

"Nor can a soul die excep1 by Allah's lcave. The term being fixed as by writing."

This means that there is a definite tine of death even though as physicians we attenipt to predict that exact time. Also, we are told that death is certain 10 catch up with you wherever you are and you cannot escape it.

"Say, death from which ye flee will truly overtake you. " 17

"Wherever you are, death will find you even if you are in towers built up strong and high.":13

Rasū-AJ]âh [PBUH] has Ieft us the instructions about how the living should deal with their grief. Ion-'Umar [RAA] narrated the following passage from his father, who learned it from the Prophet [PBUH]:

"The deceased is tortured in his grave for the wailing done over him."'

'Anas ibn Malik [RAA] narraled:

"...we entered 'Abü Sir's house and at that time lbrahim was on his last breath and the eyes of Allāh's apostle started shedding tears. Abd-ur-Rahnmān ibn 'üs said, 'O Allāh's apostle, even you are wecping.' He said 'O ibn 'uf this is mercy.' Then he wept more and said, 'the cyes are shedding tears and the heart is grieved..." is

Thus. Muslims understand that loud wailing is not allowved wlyle quiet weeping with grief is appropriate. Mourning is not allowed for more than three days, as the prophet stopped people in Medinah from mourning after the third day of Slualiadah (martyrdom) of his beloved uncle and friend, Humzah [RAA].

There are many rituals undertaken at the timc of death in different cultures, such as shooting arrows in the air (by American Indians) or shooting rifles or guns (military honor in most westem countries). Muslims have no such noisy rituals.

Muslim custons are minimal and simple: wash, bathe, and shroud the dead body and then bury it in the grave after farewell prayers have been offered by the group of family and friends. Emphasis is on quickly burying the deceased. In the grave, the face of the dead body is turned toward the Ka'abah (in Makkah, Saudi Arabia). The most common prayer is "O Aläh, forgive our dead ones and living oncs, present ones and absenl ones, men and women, older and younger, all. O Alläh whoever of us you let live, let him live in Islam and to whoever of us you give death, let him die oll "Imän" ([ail)). ${ }^{16}$

When you sea a funcral procession, stand up if you are silting (for respect). Join in ir you can and give a helping shoulder in carrying the casket. Recite the Shahädah. 'Ams ibn Räbi' [RAA], who was narrating the prophel [PBUH] sidd, "Whenever you see a funeral procession stand up until Jie procession goes ahead of you." 17

The concept of life after death and teachings such as "renicmber death frequently that destroys your enjoyments" are strong in Islam. ${ }^{18}$ In America, ". . 69\% of the adult population affirmed a belief in an afterlife. However, this belief is not held deeply enough to provide much psycho- logical reassurance. What prevails is the implicit belief for most of us, that death means the end."19 In contrast, a Muslim, while in this world, must prepare for the other world.

Allāh says in the Qur'an,

". . at length ye will dic. Again on of the day of judgment will ye be raised up." ${ }^{n 0}$

Thus, we see that death is actually but the end of one phase for a soul and a new phase begins after that.. In facl, in most of the Muslim world. Uie death of one person is referred to as "Intiqäl," which means transfer. Thus, Alläh teaches that death is the end of one plase and beginning of the next phase for a soul. We as Muslims are urged to prepare ourselves for the day of judgment; that is the reason all these things about death and the day of judgment have been comnunicated to us by our Creator.

What is actually happening 10 a soul? Souls (Rühs) or spirits of all human beings have been crcated and reside in a world of souls from where a soul comes to join tlse body (according to Allāh's will and decree). The soul (Rüh) remains in an intermediate state, or "Alm-al-barzakly," until it is time for all souls to be reunited with their bodies at the time of resurrection.

This is the knowledgc of the unseen and comes from the teachings of the Qur'än and Hädith (Proplice Muhammad's [PBUH] sayings).

Note: The views expressed in this article are those of the author and have no connection with the Deparlment of Veteran AfJairs of the U.S. government.

\section{References}

1. The Glorious Qur'an. Clapter 21: Verse 35.

2. Kubler-Ross, E: On Death and Dying. New York McMillan Publishing Co., 1969.

3. Encyclopedia Americana. Reincarnation. Danbury, Connecticut: Grolier, Inc, 1984;23:348-9.

4. The Glorious Qur'ăn. Chapter 5; Verse 106.

5. The Glorious Qur'an. Chapter 2; Verse 180.

6. Mishkät-ul-Maşäbīh. English translation by James Robeson. Lahore, Pakistan: Sh.M. Ashraf, Kashniri Bazar. $1: 334$

7. The Glorious Qur'än. Chapler 6: Verse 61

8. The Glorious Qur’an. Chapter 6; Verse 60

9. The Glorious Qur’ān. Chapter 39; Verse 42.

10. The Glorious Qur'an. Chapter 17; Verse 85.

11. The Glorious Qur'ān. Chapter 3; Verse 145

12. The Glorious Qur'ān. Chapter 62; Verse 8.

13. The Glorious Qur'än. Chapter 4; Versc 78.

14. Sahịh al-Buklkiri. English translation by Dr. MM KJan, Volume II. Chapter 33, Hadith \#379, Page 213: Kä.ї Publicalions.

15. Sahịh al-Bukhài, English translation by Dr. MM Khaı, Volume II, Chapler 42, Hadith \$390, Page 219: Kää Publications.

16. Riyādul-ulāilịin, English translation by S.M. Madni 
Abbasi, al-Imam al-Nawawi: Dar-ul-'Arabiah, Beinut, Lebanon. 483.

17. Salyih al-Bukhari, English translation by Dr. M.M. Khan, Volume [1, Chapter 45, Hadith \#394, Page 222: Káai Publications.

18. 'Ihyā' 'ulūm-ul-Dín by al-Imam al-Ghazäli, Urdu translation by $M$. Ahsan Chapter on Death and After Death: Lahore, Pakistan: al-Maktabah al-Rahmāniyyah, Urdu
Bazar. 728.

19. Encyclopedia Amcricana. Danbury, Connecticul: Grolier, Inc., 1984;8:565.

20. The Glorious Qur'ăn. Chapter 23; Verse 15-16.

English translations of the Qur 'an used here are either by Marmaduke Pictahal or Yusuf Ali. 